\title{
E-Government Adoption in Developing Economies: A G2B E-Government Perspective
}

\author{
Adu Adolph Sedem Yaw \\ Ho Technical University \\ P.O. Box 217, \\ Ho, Ghana
}

\author{
Agbenorto D. Mawuli \\ Ho Technical University \\ P.O. Box 217, \\ Ho, Ghana
}

\author{
Shadrack Bortier Quaye \\ University of Ghana \\ P.O. Box LG 25, \\ Legon Accra
}

\begin{abstract}
The government of Ghana in 2014 initiated an e-government service (e-Tax) to boost its Tax operations. With egovernment, citizens and businesses are able to exploit Internet technology to improve convenience, accessibility and quality of interactions with the government. Within the government, business processes can be automated and knowledge can be managed efficiently, thus, improving the speed and quality of policy development, coordination and enforcement. The purpose of this paper is to examine the awareness and adoption of the e-government services by private businesses in Ghana. To achieve these, this research undertook an empirical examination of the awareness and adoption of the e-Tax service amongst businesses in Ghana. A framework consisting of environmental factors, user attitude, and access to ICTs was employed to provide insights of the adopters and non-adopters of the e-Tax e-government initiative. The data on these variables were collected using a self-administered questionnaire. The study sampled 212 businesses in Ghana and use partial least square method to analyze the data collected. The findings revealed that businesses located in the urban centers are more likely to be aware of, and adopt e-government services. The study also found that a business's trust and perceived ease of use of the GRA e-taxpayer portal has a significant impact on their attitude towards the adoption of e-government services. This study offers substantial contribution to various stakeholders including the government agencies that might want to understand the factors that influence the use of an egovernment service.
\end{abstract}

\section{Keywords}

e-Tax, E-Government, Adoption, Awareness, perception, Ghana, developing economies, Government-to-Businesses, Eservice.

\section{INTRODUCTION}

Information technology innovations such as the internet and the world wide web offers opportunity to improve the efficiency and effectiveness of governments and the accessibility of government information and services to citizens [1]. Every government owes some service responsibilities to its citizens. When these services are provided electronically, they are referred to as e-government services.

E-government helps governments to achieve greater operational and cost efficiencies in performing their administrative functions and improve public service delivery by providing efficient, convenient and less costly means in accessing government information and services [1].

E-government is the use of information technology, especially telecommunications, to enable and improve the efficiency with which government services and information are provided to citizens, employees, businesses, and government agencies
[2]. Although there is a great body of literature that discuss eGovernment in developed countries, e-government literature in developing countries is scarce [3]. Indeed, Urbina (2017) stressed that there is little literature on the state of egovernment adoption in developing countries. Moreover, studies on e-government adoption especially in developing countries has focused more on individual citizens rather than on privately owned businesses [1] [4] [5]. It is therefore imperative to turn some attention to the way e-governance is adopted from the business perspective. Businesses play a pivotal role in the development of an economy; their cooperate governance, and economic activities goes a long way to sustain national growth.

What makes this study even more unique is the introduction of firm characteristics in studying the adoption of egovernment service. This study is arguable the first to factor the firm's characteristics in the adoption process of an egovernment service. Furthermore, [4] pointed that future research is essential to get a more complete picture of the perceptions and attitudes of the users of e- government services. In light of this, the study as part of its objectives aims to unearth user perception of a particular e-government service in Ghana.

The government of Ghana recently started the adoption of egovernment services. One of the pronounced of these services is the Ghana Revenue Authority's (GRA's) platform for filing tax returns and other tax-related filings. This study aims to explore the issues surrounding the adoption of this government e-service platform; by probing how private businesses are adopting the government service. The specific objectives for the studies were to:

- To find out business's perception of the e-Tax portal service.

- To find out the factors that influence the awareness and use of the e-Tax portal.

\subsection{Study Settings}

This research studies an e-government initiative by the government of Ghana to enhance tax revenue collection. The e-government service understudy is known as the "e-Tax Portal". The specific government set-up that oversees this service is the Ghana Revenue Authority (GRA). The Tax Payer Portal (i.e. e-Tax Portal), is an online portal that was implemented in 2014. The Portal supports the core functions of the GRA by offering the following online services to Taxpayers: Online Registration; Online Tax Management; Online Tax Return Filing; and Online Payments [6].

e-Tax is intended to support the GRA's TIN re-registration campaign through its online TIN Registration feature. Additional functionality includes provision of Taxpayers with the ability to view their Tax Account, Manage Tax Types, File Returns, Request Exemptions and Apply for Tax Refunds online as well as make payments through the new Ghana e- 
Payment Platform [6]. Some of these functionalities of the eTax portal are yet to be effected, albeit some are already functional.

\subsection{Conceptualizing E-Government Services}

There are different forms of e-government services including: government to government, government to business, and government to citizens; these define the services or interaction between the government and other governmental establishments, and between the government and privatelyowned businesses, as well as between the government and individual citizens respectively. The Organization for Economic Cooperation and Development (OECD) defines egovernment as the use of ICTs, and particularly the Internet, as a tool to achieve better government [7]. In general, the employment of ICTs and the Internet in the administration of government functions and in the delivery of public services is described as electronic government or e-government [1]

\subsection{E-Government Services}

Studies on the adoption of e-government in literature can be categorized into two groups, namely, the supply-side and the demand-side [8][1]. The supply-side is concerned with factors (e.g., information technology infrastructure, financial resources for IT development, number of e-government initiatives implemented) that are essential to the government as the supplier of public services [8]. The demand-side perspective of e-government adoption, explores factors that are important to the clients of the government or consumers of public services [8]. This study is of the latter group, which is the demand-side of e-government adoption. Further, a cursory examination of the literature on e-government reveals that government could engage e-governance at three generic levels. These are the government to government; government to citizen; and government to business. Again, the study focuses on the later (i.e. government to business) - which describes the ICTs to handle and support the dealings between the government and a business establishment.

\subsection{Awareness and Perception of E- Government Services}

Extant literature reveals that organizations and individuals may hold certain perceptions about an e-government service. Chief amongst the issues of perception is related to trust. AlAwadhi \& Morris [9] conducted a study on the perception of e-government services and revealed that many participants thought that if e-government services were not secure enough; their personal data would be under threat and could be altered or misused by hackers. Their findings highlight trust as a key issue of concern when creating an impression about an egovernment service. These perceptions were gained from stories about hacker attacks, Internet crime and theft of credit card details [9]. In consistent with the aforementioned findings, [10] aver that users' trust of e-government services is associated with security and privacy assurances provided to users.

With regards to awareness, Chen \& Dimitrova [11] firmly stated that a potential user's awareness of an e-government services is grossly responsible for their usage of the service. Other studies have also shown that awareness has greater impact on usage of an online service when it is engaged at the preliminary stages of implementing the online service [10]. Attractive presentations in various media, such as newspapers, radio, television and the World Wide Web, are useful for introducing e-government services to a large number of potential users and for educating those users about the benefits the new technology offers [9]. In contrast BeynonDavies [12] argues that awareness of the availability of an online service (an e-government service for that matter) will not necessarily help with their take-up.

\subsection{Determinants of the Adoption Of E- Government Services}

The implementation and adoption of e-government are extensively discussed in literature [7]. Urbina \& Abe [1] conducted a study on citizen-centric perspective on the adoption of e-government in the Philippines, and suggested that socio-demographic factors; access to ICTs and the Internet; and attitude towards e-government form the core determinants of e-government awareness and adoption. Also, perceived reliability of a technological innovation has a profound effect on its adoption [13]. Resolving security and reliability issues are critical in the widespread adoption of web services [14]. In fact, Lippert \& Govindrajulu [13] proposed that "the higher the perceived security concerns of the service, the less likely web services will be adopted and used".

\subsection{Conceptual Framework}

The study models a conceptual framework along the framework of Urbina and Abe [1] as theoretical lens to guide the research (see Figure 1, below):

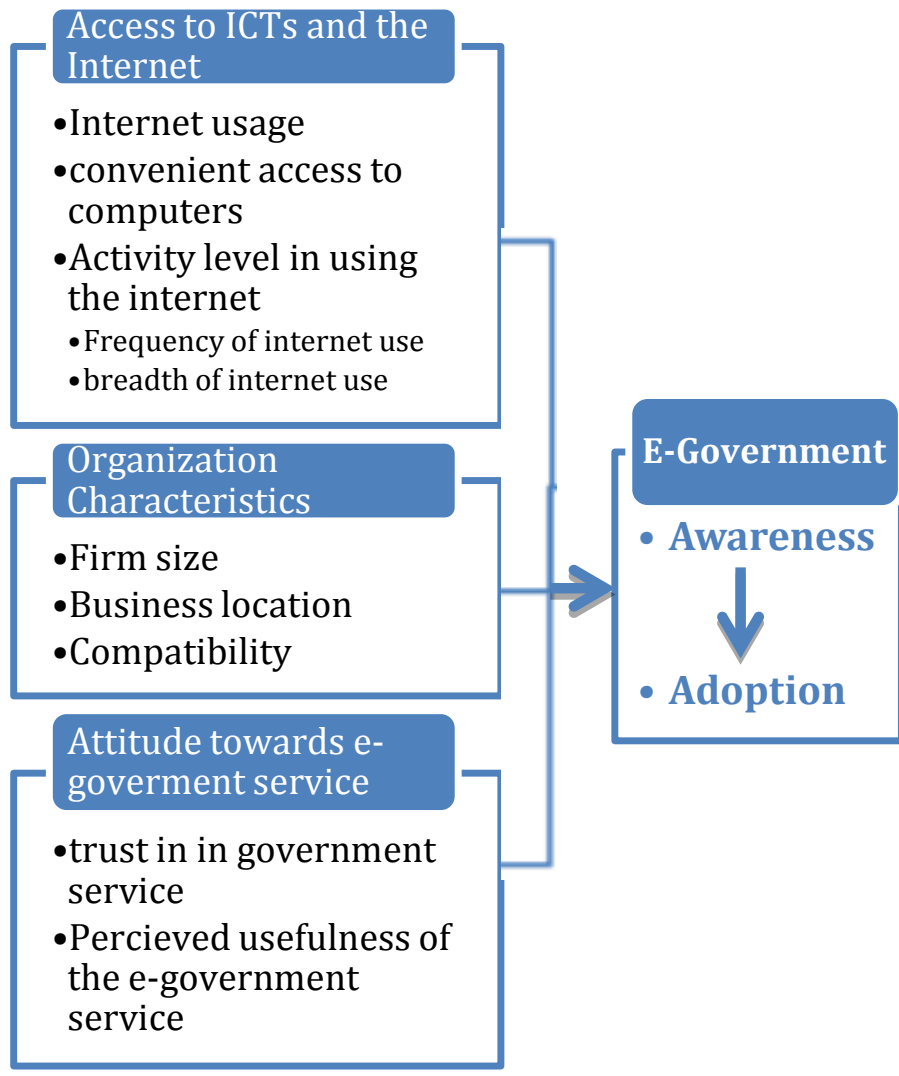

SOURCE: Adapted from [1]

\section{Figure 1: Level of Awareness of E-government Service}

Figure 1, demonstrates that access to ICTs and Attitude towards the e-government service grossly determines the awareness and consequent adoption of the e-government service. The original model identified socio demographic variables as a determinant; however, these variables are very much specific to individuals rather than organizations 
[1][15][16]. Consequently, the socio demographic variables (such as sex, marital status, religious affiliation, migration background and ethnicity) are excluded from analysis, as this study deals with business organizations rather individual citizens.

The model introduces another variable that has been documented as instrumental in the adoption of technological innovation (in this case e-governance), which is the organization characteristics [13][17]. Lippert \& Govindrajulu [13] used the TOE framework in their study of web service and emphasised the role of the organisation in adopting a web-service.

\section{METHODOLOGY}

The study employed a survey design to explore the issues surrounding the adoption of the GRA electronic/online platform for filling tax returns. The survey assessed businesses' perceptions and awareness of the e-Tax portal. Data was analysed using quantitative methods, including a partial least square regression analysis and Parsons Correlation.

\subsection{Population and Sampling}

In order to explore how businesses are adopting the GRA egovernment service, the study targeted non-governmental businesses in the Greater Accra and Central regions of Ghana. These regions were selected due to convenience: to allow the researcher to make quick follow-ups on data gathered. And also, to create a fair balance between rural and urban businesses (where Greater Accra is urban and central region is the rural). A random sampling technique was used to select 125 businesses each from the Greater Accra and Central Regions as respondents for the survey. However, only 112 and 100 questionnaires were returned and answered properly for Greater Accra and Central Region respectively.

\section{DATA ANALYSIS AND DISCUSSION OF STUDY FINDINGS}

This section provides an analysis, and the findings of the study in relation to the research objectives. The study employed the use of both descriptive statistics and a partial least square regression.

\subsection{Awareness of E- Government Services}

The first objective of the study was to find out business's awareness (and perception) of the e-Tax portal of egovernment service.

The findings revealed that, the level of awareness of egovernment services was generally low. This was confirmed by $32 \%$ of the respondents as shown figure 2 below.

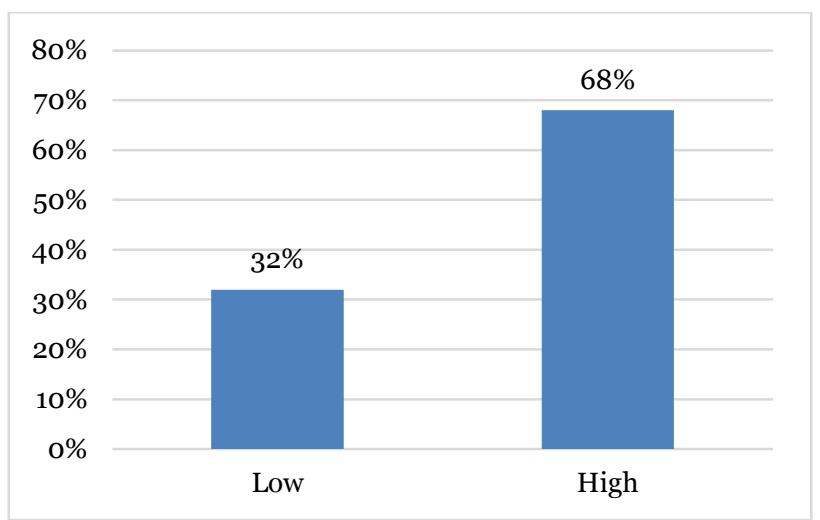

Figure 2: Level of Awareness of E-government Service
Among the very few who had some level of awareness of the e-Tax government service, quite a number of them attested to having adequate knowledge on how to use the online service.

On user perception, Table1 shows a weighted means response of the respondents in relation to their perceptions on the impact of e-government to citizens. From the table it is observed that, generally most of the respondents believed the e-government services were easy to adopt and use. This was confirmed when most of them said, e-government services were easier to use in relation to searching for information. They also mentioned of the fact that, transacting businesses on these platforms is usually without much effort and these platforms or e-government services serves as a means by which citizens of a country gets closer to the government as shown on Table 1. Furthermore, it was revealed that, quite a number of the respondents believed e-government services to citizens serves as a means by which the government can increase its service quality as well as improve on the communication between citizens and the government.

Table 1: Perception of E-government services

\begin{tabular}{|l|l|}
\hline Perception & Weighted Mean \\
\hline Easier to search for information & 4.22 \\
\hline $\begin{array}{l}\text { Transactions are performed nearly } \\
\text { effortless }\end{array}$ & 4.31 \\
\hline $\begin{array}{l}\text { Bring citizens closer to the } \\
\text { government }\end{array}$ & 4.12 \\
\hline $\begin{array}{l}\text { Increase the government's quality } \\
\text { of service }\end{array}$ & 3.01 \\
\hline $\begin{array}{l}\text { Improve communication between } \\
\text { citizen and government }\end{array}$ & 3.12 \\
\hline
\end{tabular}

\subsection{Factors responsible for e-Tax adoption}

The second research objective attempts to find out the factors responsible for the adoption of the e-Tax portal. This was measured with a framework of three possible determinants. Namely: the characteristics of the organization, the organization's IT infrastructure, and the attitude toward the eTax portal. The findings under each of the aforementioned have been discussed below:

\subsubsection{Organizational Characteristics}

The findings revealed that, the characteristics of an organization played a critical role in determining the awareness and adoption of e-governance in Ghana. In this study, organizational characteristics were measured with three parameters namely; Firm size, business location and compatibility. Two of these (firm size and business location) characteristics strongly tested positive with awareness and adoption of e-governance in Ghana. This was confirmed with a Pearson Correlation conducted at the 0.05 significance level which produced R-values of 0.783 , and 0.710 with $p<0.05$ for firm size and business locations respectively, while compatibility recorded 0.125 with $\mathrm{p}>0.05$. However, in relation compatibility, the result showed an insignificant relationship. This information gives the indication that, in relation to firm size, organizations with larger firms with relatively more employees are more likely to be aware of egovernance in Ghana, as well as adopt it. Furthermore, in relation business location, business that are located in the urban areas of Ghana showed more awareness of e- 
governance and were more likely to adopt e-governance than businesses that were located in the rural areas of Ghana.

\subsubsection{IT Infrastructure}

The IT infrastructure constituted internet accessibility, access to computers, and activity level in using the internet. All the aforementioned constituents of IT infrastructure were significant determinant of e-governance awareness and adoption in Ghana. This was confirmed with a Pearson Correlation and a regression analysis conducted at the 0.05 significance level. The test showed an $R=0.884$ and $p<0.05$ to give the indication that, there was a positive and significant relationship between IT infrastructure and internet accessibility, access to computers and activity level in internet usage. The study further showed an $\mathrm{R}^{2}=0.782$ to give the indication that, $78.2 \%$ of the changes that occurs in IT infrastructure in relation to e-governance awareness and adoption were explained by internet accessibility, access to computers and activity level in internet usage. Furthermore, the results showed coefficients values of $0.602,1.236$ and 0.115 with $\mathrm{p}<0.05$ respectively. This information gives the implication that, internet accessibility, accessibility to computers and activity level in the internet usage does have a significant impact on determining whether or not an organization or use will adopt and implement e-Tax payer system and other e-government services.

\subsubsection{Attitude Towards E-Government Service}

A regression analysis revealed that, users' attitudes towards an e-government service directly affects whether or not they will subscribe to that service. The attitude of users was measured by trust and perceive ease of use of the GRA etaxpayer portal services. The regression result showed a Pearson correlation value of 0.812 and 0.793 with $p<0.05$ to imply a very strong, positive and significant relationship between trust, perceive ease of use with attitude towards adoption of e-government services. Furthermore, the study showed an $\mathrm{R}^{2}=0.883$ to also give the indication that, $88.3 \%$ of the changes that occurs attitude towards e-government service adoption were explained by trust and perceive ease of use of these services. Finally, the result showed coefficients of 0.772 and 0.912 with $p<0.05$ for trust and perceive ease of use respectively. This result gives the implication that, trust and perceive use of the GRA e-taxpayer portal service from the perceptive of the users had a significant impact or effect on their attitude towards the adoption of e-government services.

\section{CONCLUSION\& RECOMMENDATIONS}

This study offers vital contributions to different stakeholders including decision makers and government establishments who would require adopting of an e-Government service to improve the interaction and services between government agencies and businesses.

In general, the level of awareness of e-government is very low and the participation of businesses in rural centres in the e-tax portal e-government service is very low. Here, it is recommended that government takes up initiatives to disseminate information about e-government services and how it can be used. This will help increase awareness and provide better perception of the e-government services. As regard the same, private organizations and (internet) service providers are admonish to invest into infrastructure in rural areas to encourage access and use of e-government services. The government can get the advantage of the high level of the positive perception of the current e-government service to introduce similar government services online. The study equally provides a backbone of literature for further research.

Despite the fact that the study focused on small sample size which might have limited the generalizability of the findings of this study, the research provides useful insights into the determinants of e-government service usage by private businesses in developing countries like Ghana; and how these firms may perceive an e-government services.

It is recommended that future studies in this area (i.e. egovernment services) should engage a larger sample size to strengthen the generalizability of its findings. Other studies could also follow-up on the findings of this study, by finding out what is responsible for the low levels of awareness and participation of rural-cited business organisations in egovernment initiatives.

\section{REFERENCES}

[1] Urbina, A.U. \& Abe, N., 2017. Citizen-centric Perspective on the Adoption of E-Government in the Philippines. The Electronic Journal of e-Government Volume, 15(2), pp.63-83.

[2] Carter, L. \& Belanger, F., 2004. Citizen adoption of electronic government initiatives. 37th Annual Hawaii International Conference on System Sciences, 2004. Proceedings of the, $0(\mathrm{C})$, p.10 pp. Available at: http://ieeexplore.iee.org/lpdocs/epic03/wrapper.htm?arn umber $=1265306$.

[3] Rabaai, A.A. et al., 2015. Adoption of E-Government in Developing Countries : the Case of the State of Kuwait. , 6(10), pp.77-101.

[4] Jyoti, C. \& Yogesh, D., 2005. a Survey of Citizens , Awareness and Adoption of E-Government Initiatives , the " Government Gateway ": a United Kingdom Perspective. Iseing.Org, 5, pp.1-13. Available at: http://www.iseing.org/egov/egov05/source files/papers/cameraready-5-p.pdf.

[5] Rahim, A.A. \& Athmay, A. Al, 2013. Citizens Perceptions towards e-Governance: Field Study. , 7(9), pp.631-639.

[6] GRA, 2012. GRA Tax Online Goes Live. News. Available at: https://egovonline.gegov.gov.gh/Eghana Web/GRAHome/eghana.portal;jsessionid=2jCyZJQPJKs 2SJRzGxnGWW1jZhNpr5tyZHPzOrMzgK7dpqG9NXFy !-1566943566?_nfpb=true\&_st=\&_pageLabel=gra _ newsDetails_page\&newsId=1474\#wlp_gra_newsDetails _page [Accessed June 18, 2017].

[7] Organization of Economic Cooperation and Development (OECD), 2003. The e-Government Imperative, Paris, France: OECD Publications Service.

[8] Reddick, C., 2005. Citizen interaction with egovernment: From the streets to servers?. Government Information Quarterly, 22(1), pp. 38-57.

[9] AlAwadhi, S. \& Morris, A., 2009. Factors influencing the adoption of e-government services. Journal of Software, 4(6), pp.584-590.

[10] Jaruwachirathanakul, B. \& Fink, D., 2005. Internet banking adoption strategies for a developing country: the case of Thailand. Internet Research, 15(3), pp.295-311. Available at: http://www.emeraldinsight.com/doi/ 10.1108/10662240510602708. 
[11] Chen, Y.-C. \& Dimitrova, D. V, 2006. Electronic government and online engagement: citizen interaction with government via web portals. International Journal of Electronic Government Research (IJEGR), 2(1), pp.54-76.

[12] Beynon-Davies, P., 2005. Constructing electronic government: the case of the UK inland revenue. International journal of information management, 25(1), pp.3-20.

[13] Lippert, S.K. \& Govindrajulu, C., 2006. Technological , Organizational, and Environmental Antecedents to Web Services Adoption. Communications of the IIMA, 6(1), pp.146-158.

[14] Shah, J.R. and Murtaza, M.B. (2005). Effective Customer Relationship Management Through Web Services. The
Journal of Computer Information Systems 46(1), 98-109.

[15] Gupta, K.P., Singh, S. \& Bhaskar, P., 2016. Citizen adoption of e-government: a literature review and conceptual framework. Electronic Government, an International Journal, 12(2), p.160. Available at: http://www.inderscience.com/link.php?id=76134.

[16] Zafiropoulos, K., Karavasilis, I. \& Vrana, V., 2012. Assessing the Adoption of e-Government Services by Teachers in Greece. Future Internet, 4(4), pp.528-544. Available at: http://www.mdpi.com/1999-5903/4/2/528/.

[17] Pan, M.-J. \& Jang, W.-Y., 2008. Determinants of the adoption of enterprise resource planning within the technology-organization-environment framework: Taiwan's communications industry. The Journal of Computer Information Systems, 48(3), pp.94-102. 